\title{
A Psychrophilic Yeast from Mammoth Cave, Kentucky
}

By David Brashear, Ralph F. Wiseman and Thomas C. Barr, Jr. ${ }^{1}{ }^{2}$ )

In the course of our study of the indigenous microflora of Mammoth Cave, Mammoth Cave National Park, Kentucky, we have repeatedly encountered a yellowish, mold-like organism growing on dead crickets (Hadenoecus subterraneus Scudder), dead cave rats (Neotoma magister Baird), and on meat and fish baits placed in the cave to attract arthropods. The organism has been observed throughout the upper regions of the cave, especially in those areas which receive vadose waters percolating downward from the surface. The mean temperature of these areas is $13^{\circ} \mathrm{C}$. and the relative humidity is very near saturation at all times.

A sample of the organism was collected aseptically from a section of the cave (Radio Room, near Frozen Niagara) which is not open to the public and was subjected to microbiological examination. Pure cultures were obtained by plating on Difco Cornmeal agar and incubating at $20^{\circ}$ and $37^{\circ} \mathrm{C}$. The organism, which was not pigmented in the culture, proved to be diphasic, producing yeast-like colonies at $37^{\circ}$ and filamentous growth at $20^{\circ}$. Direct observation of microcultures incubated at $20^{\circ}$ revealed pseudohyphae with chlamydospores, while microcultures incubated at $37^{\circ}$ revealed budding, ovoidal cells. Good growth was obtained on Saboraud's agar and on sterilized chopped beef after 24 hours at $13^{\circ}$. These cultures contained ovoidal cells and pseudohyphae.

After three transfers on Cornmeal agar, the organism ceased growing at $37^{\circ}$, but growth was readily obtainable at $20^{\circ}$ and at $13^{\circ}$.

The organism fermented glucose, galactose, and maltose, but not sucrose or lactose, and produced a "feathery" mycelial growth on eosin-methylene blue agar.

\footnotetext{
1) Departments of Microbiology and Zoology, Institute of Speleology, University of Kentucky, Lexington, Kentucky, U.S.A. 40506.

2) This investigation was supported in part by a grant (G18765) from the National Science Foundation.
} 
Since the organism had many of the characteristics of Candida albicans (Lodder and Krieger-Van Rij, 1952), we attempted to determine its pathogenic potential in both warm- and cold-blooded animals. One ml. of a saline suspension of the cave yeast was injected intravenously into a rabbit and intraperitoneally into frogs. The known pathogen Candida albicans (Coyle strain) was injected into other animals and served as the control. The rabbits were held at room temperature for 12 days and the frogs at $13^{\circ}$ for one month. None of the animals died. After sacrifice, internal organs of the animals were examined; only the rabbit injected with the Coyle strain exhibited pathological conditions. The cave yeast, while not pathogenic and not recoverable from the rabbit, was cultured from the livers and peritoneal exudates of the frogs.

These results suggest that this yeast is a psychrophilic strain of C. albicans which - at least in rabbits - is non-pathogenic but shows a low grade parasitism in frogs.

\section{ACKNOWLEDGMENT}

We wish to express our appreciation to the Superintendent and staff of Mammoth Cave National Park for making this investigation possible.

\section{SUMMARY}

Samples collected in Mammoth Cave, Kentucky, revealed the presence of a psychrophilic yeast, tentatively identified as a strain of Candida albicans. The yeast is saprophytic on dead animal tissues and exhibits a pale yellow color when growing in the cave. In vitro, the yeast grows poorly at $37^{\circ} \mathrm{C}$. and well at $13^{\circ}$ and $20^{\circ}$, but loses its pigmentation. It is non-pathogenic in rabbits but appeares to show low-grade parasitism in frogs.

\section{ZUSAMMENFASSUNG}

Proben aus der Mammut-Höhle (Kentucky) zeigten, daß eine psychrophile Hefe, wahrscheinlich eine Candida-albicans-Rasse, in dieser Höhle vorkommt. Die höhlenbewohnende Hefe existiert als Saprophyt auf Geweben toter Tiere und zeigt eine überall bleichgelbe Farbe. In vitro wächst diese Hefe dürftig bei $37^{\circ} \mathrm{C}$, aber rüstig bei $13^{\circ}$ und $20^{\circ}$, unter Verlust des Pigments. Bei Kaninchen ist sie nicht pathogen, und bei Fröschen zeigt sie nur milden Parasitismus.

\section{REFERENCE}

Lodder, J., and Krieger-Van RiJ, N. J. W.(1952) - The Yeasts: A Taxonomic Study. Amsterdam: North-Holland Publ. Co. Pp. 471-474, $536-538$. 